\title{
PROGRAM, STRATEGY AND TACTICS OF COMMUNIST MOVEMENT IN CONTEMPORARY EPOCHE
}

Keywords: communism, Communist Party of Poland, Marxism, political movements

\begin{abstract}
The aim of this article is to analyse Communist Party of Poland as the party of Polish proletariat, working class that represents also the interests of other Polish working peoples. Emphasis is placed The strategy of CPP is like other communist parties, socialist revolution, socialism and in the further time communism. The CPP is based in its struggle on the theory of Marxism-Leninism and the progressive tradition of the building of socialism in former People's Republic Poland.
\end{abstract}

It is stated that recently in Poland we can see worrying process with a significant increase of international tensions, also propaganda of aggressive chauvinism, as well as political persecutions, directed against dissenters, which are incompatible with international norms of human rights. Author concludes that the party program evolved from strategic goals, but tactics is limited by the contemporary class conditions and total domination of Polish and international bourgeoisie forces. It must be noted that the contemporary world is different economic, social, culture and historical and every Communist Party on the base of Marxist theory and ideology is building the strategy, program and tactics adequate to its national conditions

1 Professor emeritus of the University of Wrocław, z.wiktor@gazeta.pl. 


\section{GENERAL THESIS ABOUT THE THEORY, PROGRAM, STRATEGY AND TACTICS OF COMMUNIST MOVEMENT}

The theory of Communist Movement was and is Marxism, especially on the XIX century, in XX century Marxism developed in different schools and its contemporary face annexed through the political and theoretical activity of Vladimir I. Lenin as the Marxism-Leninism. Now at the beginning of XXI century the former versions of marxism and marxism-leninism were questionable and theoretical weak and international communist movement must to develop marxism to the new era of the developing of production forces in the era of knowledge, new contradiction between capital and labour, globalisation and great threats of global nuclear war, new definition of the contemporary proletariat and working class and forms of class struggle.

The great career plays since 40 years the Chinese "Socialist Market Economy”, „Market Socialism” and „Chinese Model of Socialism”. In my opinion it isn't Socialism as a $1^{\text {st }}$ phase of Communist Formation, but transition period between capitalism and socialism. Communist Party of China is a continuator of developing of marxism-leninism, but after death of Mao Zedong won the faction of „market socialism” under leadership of Deng Xiaoping, which expressed more Chinese culture, civilisation, level of the development of backwardness social forces, that C.Marx named to the antique time „Asian type of production”.

CPC partially come back to the theory of ancient philosopher Confutse, for example the theory of „social harmony” on the place of Marx' category of „class struggle”. The Chinese model of „market socialism” is popular in undeveloped postcolonial states of Asia, Africa and Latin America. Many western marxists expressed the negation of the theory and praxis of the "Chinese model of Socialism” and they determine it as the „state capitalism” or „vulgar socialism”. Now after the $19^{\text {th }}$ National Congress (October 2017) CPC expressed more the class character of the party and it look for more contacts and discussions with other communist parties. It's maybe a promise to the discussion about the establishing a new Internationale.

The contemporary world is different economic, social, culture and historical and every Communist Party on the base of marxist theory and 
ideology is building the strategy, program and tactics adequate to its national conditions, but in united front of the International Communist Movement. We need decide a new Communist Internationale.

History has shown that previous form of the socialist system, that was successful in its initial phase in striving for creation of the classless society and in the next phase collapsed and fell in the USSR and European people democracies, does not mean however the final defeat of struggle for classless system.

This aims followed after the fall of the USRR and people democracies, by several non-European socialist states, primarily China (despite the fact their development in this direction is questionable). General further progressive development of China and to great extent related fast development of many backward countries, and great technical progress in highly developed states, not fitting frames of further existence of the capitalist system, undermines myth about inevitability of class exploitation and shows chances for its liquidation and replacement by classless system in modern form in not far historical perspective.

\section{THE STRATEGY AND TACTICS OF THE COMMUNIST MOVEMENT IN THE ERA OF KNOWLEDGE}

The contemporary world belongs in many great contradictions and is rising the many class tensions and threats of wars, it's rising also the revolutionary situation in many oppressed and exploited countries. The basic justification of the thesis on chance of victory and successful development of classless society is still unsolved and growing conflict of modern capitalism, between development of material and not-material producing powers in fast developing era of knowledge and functioning in most countries develop capitalism- system with increasing level of exploitation of the majority of the people.

In these countries to sustain capitalism, vast majority of the society (and even more proletariat, working for its needs in backward countries) and primarily increasingly qualified white-collar proletariat, is being debased and exploited. 
In most developed states capitalist system is, in fast developing era of knowledge, an obstacle to further rational development of the society in its material and spiritual aspects. The sharpest expression of these contradictions is a fact that with gradual shortening of the obligatory work hours, ruling great capital does the opposite, forcing part of the workers to work and increasing part of the population is being treated as socially redundant.

It already causes great discontent and in near future will cause growing social resistance and sharp class struggle in which exploited majority of the population will understand, from its own experience, that still existing in the era of knowledge, system of class exploitation needs to be overthrown and replaced on the way of class struggle by classes system that will enable progressive development of the humanity.

Growing contradictions of the capitalist system in the era of knowledge do not mean however unconditional victory of the classes system, contrary to opinions resulting from simplified approach to historical materialism and dialectics.

Generally speaking development of the producing forces creates chances and using them depends from many objective and subjective factors. History has shown that many existing chances to create a classless society were wasted. Nowadays in an era of knowledge there is a biggest chance realize this aim, but it's not sure. Course of history is and will be very complicated due to coexistence of many countries with various levels of development and often contradictory economic, social and political interests and struggle both inside these countries and between them that are now shaking the world.

Sharpness of the problem of chances in struggle for classless society and its further continuous progress results from the fact that contrary to development changes in the past, these are not entirely spontaneous changes, but are mainly steered by political vanguards (communist parties) and its positive or negative outcome depends from right way of steering. In near past existing chances of creating a classless society in the USRR and peoples' democracies were wasted to great extent due to mistakes in this steering.

Also in China chances for progress in this direction were usually wasted during last year of Mao's life and nowadays it is doubtful whether present 
leadership of the CPC aspires to creation of classless society instead of for example sustaining existing class divisions in the developing economy, in a form of state capitalism. There now in the time of Xi Jinping the superiority belongs to the Chinese proletariat and working people but also had eroded the great capitalist class with gigantic private property and official and unofficial influence on the CPC and political system, the class differences are deeper, the socio-economic contradictions are stronger and the final victory of socialism is questionable and open.

During scientific research one needs to rightly analyze achievement and defeats of the past, but above all, one needs to understand fast changing world and raw adequate conclusions on social powers need to win constant classless development of the society, according to character of the producing powers in the era of knowledge.

\section{ACTUAL PROBLEMS OF STRATEGY AND TACTICS OF COMMUNIST PARTY OF POLAND}

The strategy of CPP is like other communist parties, socialist revolution, socialism and in the further time communism. The fundamental tactic is the class struggle against capitalism and for the socialism. The program of Party declared the near and further goals of tactics, also the class friends and allies. Our tactics are strong limited by the total domination of bourgeoisie forces internal and international, the Catholic church, but Polish communists say: Head up not the hands!

Recently in Poland we can see worrying process with a significant increase of international tensions, there is a never before seen rise not only of militaristic hysteria, but also propaganda of aggressive chauvinism, as well as political persecutions, directed against dissenters, which are incompatible with international norms of human rights.

Each year in Warsaw there are parades of thousands of fascists, in which are already openly raised slogans favoring the annexation of former polish east-lands and according we see a growing wave of chauvinistic nationalism. All this is masked under the pretext of an alleged foreign threat of Russia, is used for the incitement of international and interstate 
unrest, for the demonization and denigration of antisystem opposition figures and organizations.

Hand in hand with this goes a campaign of caveman-like anti communism, which manifests itself through the cynical falsification of history. Monuments dedicated to the Red Army, as well as the anti-fascist partisans are being destroyed on the basis of the so-called „Decomunisation Act”. What is more, there is the criminal case opened against the legally operating Communist Party of Poland (CPP), with the goal the banning it, threatening its members and leaders with imprisonment for the promotion of " communist totalitarian state”, „communist ideology” and „Marxism-Leninism”.

The persecutions have the long history and the legal base is formulated in art. 13 of Constitution of Republic Poland from April 1997 (the prohibition of fascist, Nazism and communist party and ideology) and in the polish penal code.

Four activists of the CPP were condemned on March 2016 by the Regional Court in Dąbrowa Górnicza for propagating communist ideology in the „Brzask „-newspaper and on the party`s website. They have been sentenced to 9 months limited freedom with compulsory gratuitous social work and fines.

The provocative verdict was taken during the summary procedure without presence of all the sides, that is usually used in offences, when guilt of the accused is certain. The court did not even undertake standard judgment procedure and based its verdict only in the charge of the Attorney General Office. The accused even had no possibility to defend themselves. The condemned had already made objections to a judgment demanding normal court proceedings.

Activists of the CPC were accused of breaching article 256 paragraph 1 of the penal code: „Whoever publicly promotes a fascist or other totalitarian system of state or incites hatred based on national, ethnic, race or for of lack of any religious denomination shall be subject to a fine, the penalty of restriction of liberty or the penalty deprivation of liberty for up to 2 years".

An earlier attempt to amend to amend this article by adding a ban on communist symbols was met with protest both in Poland and abroad. On 
$19^{\text {th }}$ of July of 2011 it was lifted by the Constitutional Court that proclaimed it contradictory with the principle of freedom of speech.

Accusations against activists of the CPP for promoting a totalitarian system are the next example of equating communism with fascism and banning communist activity.

The case was started by the denunciation made by Bartosz Kownacki - Member of Parliament of the Party of the „Law and Justice”- PiS (and next Viceminister of the Defence Ministry of Poland )in 2013. The prosecutor refused to proceed. However in 2015 proceedings were resumed and gathered pace after the parliamentary election won by PiS. On $31^{\text {st }}$ of December 2015 Regional Prosecutor's office in Katowice issued the case to Regional Court in Dąbrowa Górnicza. The act of accusation stated that activists were publicly promoting a totalitarian system, by publishing in "Brzask” (Dawn) newspaper articles „directly related with the communist system and Marxism-Leninism, which in the context of historical experience is contradictory with democratic values" - that means for the activities of a legal political party.

The case is also important in the context of the politicization of the persecutor's office by subordinating it to the Minister of Justice - Zbigniew Ziobro from PiS, who was nominated as the Prosecutor General. Now the justice system is openly treating right wing extremism differently. At the same time when members of the „Brzask” editorial staff are being sentenced, neofascists from ONR (National Radical Camp) freely demonstrated on the streets of the city Białystok (nord-east Poland) commemorating the $82^{\text {nd }}$ anniversary of their organisation. During the demonstration under the phalanx symbol they carried torches and promised to „do away” with political enemies, so directly referring to fascism. Despite this, the Ministry of Defence plan to arm neofascist as part of the territorial defense. Earlier, the court in city Częstochowa (central Poland) acquitted charges against a man selling nazi t-shirts, not seeing any violation of the art. 256 of the penal code. Recently the Minister of Justice and Prosecutor General has suspended a sentence of a nationalist sentenced for assaulting a policeman.

The verdict condemning Polish communists was taken at the same time on the $1^{\text {st }}$ April 2016 when the Parliament voted through a law „On ban- 
ning the promotion of communism" that forces local authorities to change the names of streets and other objects that are associated with communism, which is an attack against the tradition of the workers' movement. The Institute of National Remembrance (IPN) creates a registry and demands from the local authorities liquidation of the monuments of Soviet soldiers and others related to communism. The devastation and liquidation of monuments and falsifying of history are common features of fascist practices.

The polish bourgeoisie class and the government are fooling themselves if they believe that the Communist Party of Poland, the communists of Poland will be intimidated by his anti-communist persecution or that the anti-communist campaign will make them yield. The measures against the communist go hand in hand with the escalation of the barbaric antipeople political line of the reactionary bourgeoisie-government, European Union and NATO.

\section{THE DEVASTATIONS AND LIQUIDATION OF THE MONUMENTS OF RED ARMY}

Communist Party of Poland especially condemn the devastation and liquidation of the hundreds monuments and the thousands of places and streets commemorating heroes of struggle against fascism, in particularly in war world II against Hitler's Germany. In the time 1944-45 were killed more than 625 thousand Soviet soldiers and Polish people established in the thanksgiving and to memory hundreds monuments and statues and tables of fallen heroes. It was also the monuments of Polish-Soviet brotherhood in arms. The Institute of National Remembrance (IPN) has indicate about 500 such monuments, which more are liquidate. The majority of this monuments were on the lines of war fronts against nazi Germany on the river Wisła and Warsaw, in former East Prussia, in Gdańsk and Pommerania, on the River Odra, Lausitzer Neisse and many cities and places of the upper and lower Silesia where hard battles against Wehrmacht took place.

Recent examples are the dismantling of the Mausoleum of the Red Army in Trzcianka (Pommerania), Monument of the general I. Tscherni- 
akhovsky in region Olsztyn (north Poland), earlier Vladimir Lenin in Poronin in Tatra mountain and marshall K.Rokossosky in Legnica, marshall I.Koniew in Krakow, failed proof of devastation in Nikolin on river Odra, where local peoples defended and restored the monument of battle for bridge-head on the river Odra. There were collapsed the monuments of Polish-Soviet brotherhood in arms for examples in Warsaw, Legnica, Zgorzelec, Szczecin, the heroic death of general K.Świerczewski, who died in battle against Bandera Ukrainian fascist upraising army in south-east Poland (Bieszczady) and in many places on the Odra and Neisse river. Many Polish cities given the name of general K.Świerczewski, now no more. It's also the problem of many others not so prominent and famous soldiers of Soviet and Polish People's Army.

The other example of this shameful change of streets name is in the last time in Wrocław was on the 10 May only one day after the anniversary of the Great Victory against fascism. Among the street names to be changed in Wrockaw are the ones that commemorate the victims of German nazi fascism, who died in Auschwitz concentration camp. While the public heroes are attempted to be erased from social memory, CPP points out „nationalists and bandits are being promoted at new heroes. Even the preparators of war crimes and ethnic cleansing go on the street names" in order to cherish fascism.

The changes of the names of the streets and attacks on monuments of Soviet and Polish soldiers, communist partisans and militants of the worker's movement are a result of the historical policy imposed by the state authorities. It is implemented by the Institute of the National Remembrance (IPN), which is questioning even liberation of Poland by Red Army and Polish People's Army.

According to CPP, religious reactionist forces and state institutions also play a role in the right wing rewriting of history. CPP indicates ,as a result of current historical policy, the nationalist and neo-fascist movements act unpunished. With the support of the state institutions and the Catholic church, they openly organize marches and other propaganda actions. We cannote allow this, especially in a country that suffered enormous losses as a result of genocidal policies of the Nazis during the Second World War". 
Communist Party of Poland oppose the „Decomunisation Act” that imposes changes of the street and other public objects and liquidation of monuments and memorials regarded as promoting communism. In many places, during public consultations, , inhabitants nearly unanimously voiced against changing toponyms of the streets. Due to this resistance many local authorities resigned from conducting decomunisation.

The „Decomunisation Act” and the way it's being implemented show that opinion of the society is meaningless for the authorities. In frames of this act, the voivoides (local representatives of the central government) gain power to impose new toponyms where local authorities failed to change them. It is an illegal interference in competence of the local authorities, $s$ the appeals against these decisions should be addressed to administrative courts. What's more, the costs and consequences of these changes will be covered by inhabitants, even those who opposed them.

The main object of their attack are the patrons who participated in the struggle against fascism. They constitute $2 / 3$ of the list of patrons to be changes, composed by the IPN. Historical policy conducted by the authorities leads to replacing these patrons with anticommunists promoted by the IPN. Equating communism with fascism is an element of this policy, and this indirectly leads to whitewashing the later. It also promotes nationalism. The aim of this policy is not only to shape the vision of the history. But also aggressive anticommunist positions, mostly among the youth.

In this situation, the resistance against falsifying of the history is needed. The most efficient way to oppose the Decomunisation Act" is a broad social resistance. In many cities, there are campaigns to preserve of the streets and monuments. Communist Party of Poland expresses its support for the activities of the local groups and call upon all its members and sympathizers to participate in this resistance. 


\section{THE ENDEAVOURS TO RESTRICTIONS AGAINST UNIVERSITY'S AUTONOMY AND AGAINST THE SUPREME COURT}

The clerical, right forces ruled in Poland take many endeavors to restrictions and limits the liberty of scientific research and liberty of free thinking and academic discussions as a part of the freedom of the speech. In opposition to the official propaganda of the government the budget spending for the science, universities and other academic schools are every year lesser and its number it's limited. It declines the number of students. Many scholars are jobless and they must emigrate. There centralisation of the government of the universities and the tendency is promulgate by the new from 1.X.2018 Academical Act, especially increased role of the Minister of the State Academical Institutions. The function of Minister implements Dr Jarosław Gowin, also Vice-Prime minister, which represents right conservative flank of PiS Party. The liberal millieau of Universities with the unrest and threat observe the situation. It erode the discontent of the especial young scholars.

The especially outrageous example happened on the $11^{\text {th }}$ May 2018, when police entered the Conference about Marxism (200 anniversary of birthday of Carl Marx and his influence on the science and contemporary world) held by the Philosophy of Culture Department of Szczecin University in University's facilities in Pobierowo on the Baltic sea. The functionaries acting on demand of the prosecutor's office were searching for evidence of "promoting totalitarian system”.

This intrusion constituted a clear violation of the university's autonomy and constitutional right for freedom of the scientific activity. Professor organizing the Conference said the police intervention was „an attempt intimidate the scientist and to entangle them into the political order that is entirely contradictory with values such as freedom of speech and scientific research". He also stated that the basic citizen's rights are endangered.

The other form of persecutions is the reorganisation of the Polish Supreme Court and the shortening of the term of the President of Supreme Court from 6 to 4 years to remove his to retired age. This action is contra- 
dictory with art. 183/3 of the Constitution of Republic Poland ant it's a wider action of PiS government against the rule of right and principle of division of state powers (art. 10 of Constitution of RP). This all action is of course united with the changes of cadres in all judicature.

This incidents and actions are an examples of progressing violations of political and civic liberties. The persecution of political activists continues and intensifies. The trial against members of the „Brzask” editorial staff, members and the leaders of the Communist Party of Poland, accused of "promoting totalitarian system", continues for 2 years.

On $7^{\text {th }}$ May this year Facebook profiles of "Brzask” and CPP were blocked. One week earlier persecution was directed against the „Władza Rad" (Soviet Power) Internet Portal. On $30^{\text {th }}$ of April police confiscated computer and data carriers of its web administrator. On the last time (27 October) of the processing against „Brzask” and leaders of the CPP in Dąbrowa Górnicza the new stronger persecutor changed the former soften; Its shows also the new political tendency of regime.

At the same time neo-nazis promoting hate and physical disposal with opponents enjoy support of the state. Police stood on their side on the $1^{\text {st }}$ May in Warsaw, using force against the antifascist blocking neo-nazi march with participants displaying SS symbols.

\section{CONCLUSIONS}

Communist Party of Poland is the party of Polish proletariat, working class and it represents also the interests of other Polish working peoples. The CPP is based in its struggle on the theory of Marxism-Leninism and the progressive tradition of the building of socialism in former People's Republic Poland.

The strategy is the socialist revolution, socialism and in the further time communism. The program rose from this strategic goals, but our tactics are declared and limited by the contemporary class conditions and total domination of Polish and international bourgeoisie forces and the growing persecutions of bourgeoisie regime. 
We are supporting all exploited and fighting peoples against capitalism and for the socialism, for maximal united front against persecutions and wars. The class struggle goes so one and it is constantly actual slogan of Marx and Engels: Proletarier of all countries, united!

\section{BIBLIOGRAPHY:}

Międzynarodowy Ruch Robotniczy (1976). t.1, 2. Warszawa: Książka i Wiedza.

Czubiński, A. (ed.) (1974). Polski Ruch Robotniczy. Zarys historii. Warszawa: Książka i Wiedza.

Program Komunistycznej Partii Polski, uchwalony na 4. Zjeździe KPP (2016). Dąbrowa Górnicza.

Statut Komunistycznej Partii Polski, uchwalony na 1 Zjeździe KPP (2002). Dąbrowa Górnicza.

CP of Poland: „Preserve the memory of the victims of fascist crimes and the heroes of the struggle against fascism". ICP, 16 June 2017.

KPP: 'Resistance against falsiffying of the history is needed'. ICP, 13 September 2017.

International Defense for Communism. ICP, November 2017.

CP of Poland, Members of the Communist Party of Poland condemned for propagating communism - Appeal of the CP of Poland for International Solidarity, Internet, Monday, 25 April 2018.

CP of Poland, Communist Party of Poland against the political persecution. Internet, $5 / 2018$;

International Defense for Communism. ICP, 29 November 2017. 